Piotr Chybalski

\title{
Tryb rozpatrywania przedłożonego przez Radę Języka Polskiego „Sprawozdania o stanie ochrony języka polskiego za lata 2016-2017"1
}

\author{
Procedure for considering the "Report on the state of protection of the \\ Polish language in 2016-2017" submitted by the Polish Language Council
}

\begin{abstract}
The report, submitted by the Council for the Polish Language, entitled "Language of political information", contains an analysis of the problem that is narrow in scope. In the light of the current parliamentary practice, the narrow scope of the Council's reports is typical and this has not been questioned in the course of parliamentary work. The decision of the Culture and Media Committee, resulting in a refusal to consider the document in question, is an expression of negation of the decision of the Marshal of the Sejm to recognize this document as a report. Formally, the committee proceedings on the report had not been completed. The Committee should return to examining this document and complete its work, formulating an appropriate opinion.
\end{abstract}

Keywords: Polish language, Sejm committee, Marshal of the Sejm, Standing Orders of the Sejm

Przedłożone przez Radę Języka Polskiego sprawozdanie, zatytułowane „Język informacji politycznej", zawiera analizę problemu o wąskim zakresie. W świetle dotychczasowej praktyki ustrojowej taki właśnie zakres sprawozdań Rady jest typowy i nie był dotychczas kwestionowany w toku prac parlamentarnych. Rozstrzygnięcie Komisji Kultury i Środków Przekazu, skutkujące odmową rozpatrzenia przedmiotowego dokumentu, stanowi wyraz zanegowania decyzji Marszałka Sejmu o uznaniu tego dokumentu za sprawozdanie. Formalnie postępowanie komisyjne w sprawie sprawozdania nie zostało zakończone. Komisja powinna powrócić do rozpatrywania tego dokumentu oraz zakończyć swoje prace, formułując stosowną opinię.

Słowa kluczowe: język polski, komisja sejmowa, Marszałek Sejmu, regulamin Sejmu

doktor nauk prawnych, adiunkt -

Uniwersytet Kardynała Stefana Wyszyńskiego w Warszawie, Wydział Prawa i Administracji, Katedra Prawa Konstytucyjnego, WARSZAWA, POLSKA •

piotr.chybalski@sejm.gov.pl • https://orcid.org/0000-0002-7703-1767

\section{Uwagi wstępne}

W dniu 3 lipca 2019 r. wiceprzewodnicząca Komisji Kultury i Środków Przekazu skierowała do Marszałka Sejmu pismo zawierające skargę na przewodniczącego Komisji Kultury i Środków Przekazu „w związku z naruszeniem przez niego

1 Opinia prawna w sprawie trybu rozpatrywania przedłożonego przez Radę Języka Polskiego „Sprawozdania o stanie ochrony języka polskiego za lata 2016-2017” sporządzona 10 lipca 2019 r. na zlecenie zastępcy Szefa Kancelarii Sejmu; BAS-WAKiU 1457/19, $1446 / 19$. 
w dniu 2 lipca 2019 r. podczas posiedzenia Komisji Kultury i Środków Przekazu [...] art. 12 ust. 2 ustawy z dnia 7 października 1999 r. o języku polskim”. Przedmiotem przeprowadzonego wówczas 177. posiedzenia było rozpatrzenie „Sprawozdania o stanie ochrony języka polskiego za lata 2016-2017” (druk sejmowy nr 3324), przedłożonego przez Radę Języka Polskiego i zatytułowanego „Język informacji politycznej”. Zgodnie z treścią wyżej wymienionego pisma, a także notatką z przebiegu wspomnianego posiedzenia (sporządzoną przez pracowników Biura Komisji Sejmowych) po przedstawieniu przedmiotowego sprawozdania przez przewodniczącą Rady Języka Polskiego został zgłoszony wniosek o przerwanie dyskusji, nierozpatrywanie sprawozdania oraz odesłanie go, za pośrednictwem Marszałka Sejmu, Radzie Języka Polskiego, jako niespełniającego przepisów zawartych w ustawie z dnia 7 października 1999 r. o języku polskim (Dz.U. 2018, poz. 931, ze zm.; dalej również jako: ustawa). Komisja, wysłuchawszy wniosku przeciwnego, przychyliła się do wyżej wymienionego wniosku i tym samym zakończyła obrady dotyczące wskazanego dokumentu.

Należy dodać, że w tym samym dniu (3 lipca 2019 r.) zlecenie sporządzenia opinii BAS skierował poseł Krzysztof Mieszkowski, członek Komisji Kultury i Środków Przekazu. Jakkolwiek w treści zlecenia zostały postawione trzy pytania szczegółowe, niewystępujące w powyższym piśmie wiceprzewodniczącej Komisji Kultury i Środków Przekazu, to dotyczą one tej samej sprawy (okoliczności rozpatrywania przez komisję „Sprawozdania o stanie ochrony języka polskiego za lata 2016-2017”). Z tego względu niniejsza opinia odnosi się również do tego zlecenia.

Należy zastrzec, że niniejsza opinia jest poświęcona wyłącznie proceduralnym aspektom sprawy, tj. przebiegowi sejmowych prac dotyczących rozpatrzenia wyżej wymienionego sprawozdania. Poza zakresem opinii pozostaje w szczególności merytoryczna ocena tego dokumentu.

\section{Sprawozdania o stanie ochrony języka polskiego na gruncie ustawy o języku polskim i w praktyce}

Zgodnie z art. 12 ust. 1 ustawy o języku polskim Rada Języka Polskiego jest instytucją opiniodawczo-doradczą w sprawach używania języka polskiego. Rada, na wniosek ministra właściwego do spraw kultury i ochrony dziedzictwa narodowego, ministra właściwego do spraw oświaty i wychowania, ministra właściwego do spraw szkolnictwa wyższego i nauki, Prezesa Urzędu Ochrony Konkurencji i Konsumentów, prezesa Polskiej Akademii Nauk lub z własnej inicjatywy, wyraża, w drodze uchwały, opinie o używaniu języka polskiego w działalności publicznej oraz w obrocie na terytorium Rzeczypospolitej Polskiej z udziałem konsumentów i przy wykonywaniu na terytorium Rzeczypospolitej Polskiej przepisów z zakresu prawa pracy oraz ustala zasady ortografii i interpunkcji języka polskie- 
go (art. 13 ust. 1 ustawy). Ponadto Rada może wydawać opinie, we wskazanym w ustawie zakresie, na wniosek towarzystw naukowych, stowarzyszeń twórców, szkół wyższych, organów wymienionych w art. 4 ustawy ${ }^{2}$, a także producentów, importerów oraz dystrybutorów towaru lub usługi, dla których w języku polskim brak jest odpowiedniej nazwy (art. 13 ust. 2, art. 14 ust. 1 i 2 ustawy).

W myśl art. 12 ust. 2 ustawy nie rzadziej niż co 2 lata Rada przedstawia Sejmowi i Senatowi sprawozdanie o stanie ochrony języka polskiego w rozumieniu art. 3. Powołany art. 3 ustawy nie odnosi się bezpośrednio do treści sprawozdania, lecz w ust. 1 dookreśla pojęcie „ochrony języka polskiego”, która polega na: „1) dbaniu o poprawne używanie języka i doskonaleniu sprawności językowej jego użytkowników oraz na stwarzaniu warunków do właściwego rozwoju języka jako narzędzia międzyludzkiej komunikacji; 2) przeciwdziałaniu jego wulgaryzacji; 3) szerzeniu wiedzy o nim i jego roli w kulturze; 4) upowszechnianiu szacunku dla regionalizmów i gwar, a także przeciwdziałaniu ich zanikowi; 5) promocji języka polskiego w świecie; 6) wspieraniu nauczania języka polskiego w kraju i za granicą".

Uwzględniając fakt odesłania w art. 12 ust. 2 ustawy do zacytowanego art. 3, a także nałożony na wszystkie organy władzy publicznej oraz instytucje i organizacje uczestniczące w życiu publicznym obowiązek ochrony języka polskiego, przewidziany w art. 3 ust. 2 ustawy, można byłoby prima facie przyjąć, że zakres periodycznych sprawozdań Rady Języka Polskiego powinien, co do zasady, obejmować ocenę spełnienia wyżej wymienionego obowiązku przez wskazane w ustawie podmioty. Jednak taki wniosek jawi się jako wątpliwy, gdyż z uwagi na zasygnalizowany odmienny zakres regulacji art. 12 i art. 3 ustawy nie sposób wyczerpująco ustalić zakres sprawozdań Rady. W szczególności brakuje podstaw, by uznać, iż sprawozdania te winny obejmować informacje o wykonywaniu obowiązku ochrony języka polskiego przez wszystkie podmioty wskazane w wyżej wymienionych przepisach, gdyż zadanie to jawi się jako niewykonalne z uwagi na szeroki (i nieostry) katalog tych podmiotów.

Analiza praktyki stosowania art. 12 ust. 2 ustawy wskazuje, że poszczególne sprawozdania Rady Języka Polskiego o stanie ochrony języka polskiego mają z zasady charakter opracowań tematycznych, tj. poświęconych wybranemu zagadnieniu związanemu z posługiwaniem się językiem polskim, przy czym prak-

2 Lista organów wymienionych w art. 4 ustawy obejmuje: 1) konstytucyjne organy państwa; 2) organy jednostek samorządu terytorialnego i podległe im instytucje w zakresie, w jakim wykonują zadania publiczne; 3) terenowe organy administracji publicznej; 4) instytucje powołane do realizacji określonych zadań publicznych; 5) organy, instytucje i urzędy podległe organom wymienionym w pkt 1 i 3, powołane w celu realizacji zadań tych organów, a także organy państwowych osób prawnych w zakresie, w jakim wykonują zadania publiczne; 6 ) organy samorządu innego niż samorząd terytorialny oraz organy organizacji społecznych, zawodowych, spółdzielczych i innych podmiotów wykonujących zadania publiczne. 
tykę tę należy uznać za utrwaloną i niekwestionowaną w toku rozpatrywania sprawozdań przez Sejm czy organy izby. Tytułem ilustracji: sprawozdania Rady przedłożone Sejmowi w latach 2007-2018 (w tym pierwsze dwa w VIII kadencji) zostały poświęcone następującym kwestiom:

- „Promocja polszczyzny na stronach internetowych ambasad, konsulatów i Instytutów Polskich” - „Sprawozdanie o stanie ochrony języka polskiego za lata 2015-2016" (druk sejmowy nr 1570/VIII kad.), rozpatrzone przez Komisję Kultury i Środków Przekazu 3 lipca 2018 r., jak dotąd nierozpatrzone przez Sejm in pleno;

- "Język polski w dokumentach używanych w obrocie konsumenckim” - „Sprawozdanie o stanie ochrony języka polskiego za lata 2012-2013” (druk sejmowy nr 89/VIII kad.), rozpatrzone przez Komisję Kultury i Środków Przekazu 25 lutego 2016 r., a następnie przez Sejm 11 marca 2016 r. (13. posiedzenie Sejmu VIII kadencji);

- „Poprawność językowa i sprawność komunikatywna internetowych materiałów pisemnych, kierowanych do obywateli przez ministerstwa i wybrane instytucje centralne” - „Sprawozdanie ze stanu ochrony języka polskiego w latach 2010-2011" (druk sejmowy nr 1083/VII kad.), rozpatrzone przez Komisję Kultury i Środków Przekazu 3 kwietnia 2013 r., a następnie przez Sejm 10 maja 2013 r. (38. posiedzenie Sejmu VII kadencji) ${ }^{3}$;

- „trzy obszary używania języka - środowisko biznesowe, podręczniki szkolne do kształcenia zawodowego [...] i szkolnictwo wyższe" - s. 2 podsumowania „Sprawozdania ze stanu ochrony języka polskiego w latach 2008-2009” (druk sejmowy nr 4006/VI kad.), rozpatrzonego przez Komisję Kultury i Środków Przekazu 11 maja 2011 r. $^{4}$;

- m.in. stan języka polskiego w podręcznikach do nauczania religii katolickiej w szkole w świetle ustawy o języku polskim z dnia 7 października 1999 r. oraz rok języka polskiego - „Sprawozdanie o stanie ochrony języka polskiego w latach 2005-2006" (druk sejmowy nr 29/VI kad.), rozpatrzone przez Komisję Kultury i Środków Przekazu 27 marca 2008 r. ${ }^{5}$, obejmuje kilka opracowań tematycznych.

Praktyka nadawania sprawozdaniom o stanie ochrony języka polskiego problemowego (tematycznego) charakteru została uzasadniona przez przewodniczącego Rady Języka Polskiego podczas rozpatrywania przez Komisję Kultury i Środków Przekazu sprawozdania obejmującego lata 2012 i 2013. Stwierdził on: „Trzeba powiedzieć, że pierwsze dwa sprawozdania jeszcze z przełomu wieków,

3 Sprawozdanie to zostało poprzedzone krótkim (siedmiostronicowym) opracowaniem „Działalność legislacyjna Sejmu i Senatu w latach 2007-2011 wobec wymagań ochrony języka polskiego”.

4 Sprawozdanie to nie zostało rozpatrzone przez Sejm in pleno.

5 Sprawozdanie to nie zostało rozpatrzone przez Sejm in pleno. 
z początku wieku zawierały omówienia stanu ochrony polszczyzny w różnych obszarach i dziedzinach życia, i w rozmaitych typach tekstu. [...] Następne «Sprawozdania» dotyczyły używania polszczyzny w różnych obszarach życia społecznego, m.in. w środowisku biznesowym, w witrynach internetowych ministerstw i urzędów centralnych, w podręcznikach szkolnych różnego rodzaju, w obrocie towarowym i konsumenckim, w umowach cywilnoprawnych. Wszystkie «Sprawozdania» były przedmiotem dyskusji w komisjach sejmowych i senackich, również na posiedzeniach plenarnych Senatu. Wyjaśniam to wszystko, dlatego że po prostu te «Sprawozdania», które zdajemy teraz co dwa lata, nie obejmują w całości języka polskiego. Nie ma sensu co dwa lata patrzeć, jak zmieniała się cała polszczyzna. Za każdym razem skupiamy się na wybranym fragmencie naszego języka, dokonujemy analizy, również oceny tego fragmentu"6.

\section{Rozpatrywanie sprawozdań o stanie ochrony języka polskiego przez Sejm}

Regulamin Sejmu nie obejmuje przepisów, które expressis verbis określałyby tryb rozpatrywania sprawozdań o stanie ochrony języka polskiego. Oznacza to, że dokumenty te należą do kategorii informacji, sprawozdań i raportów z działalności instytucji i organów władzy państwowej innych niż te, o których mowa w art. 124-126 regulaminu Sejmu (art. 126a ust. 1 regulaminu Sejmu). W konsekwencji ramy prawne odnoszące się do ich rozpatrywania są skromne.

Przede wszystkim kwalifikacja prawna tego typu dokumentów należy do Marszałka Sejmu, w ramach kompetencji nadawania biegu inicjatywom ustawodawczym i uchwałodawczym oraz wnioskom organów państwa skierowanym do Sejmu (art. 10 ust. 1 pkt 8 regulaminu Sejmu). Przywołany wcześniej art. 126a ust. 1 regulaminu Sejmu przewiduje jedynie możliwość rozpatrzenia takich dokumentów przez Sejm, nie zaś obowiązek ich rozpatrzenia, a jedyny wymóg regulaminowy stanowi doręczenie ich posłom (art. 126a ust. 2 regulaminu Sejmu). Nie ma przeszkód prawnych, aby przekazać tego typu dokumenty do oceny przez komisje sejmowe, gdyż zgodnie z art. 17 ust. 1 pkt 2 regulaminu Sejmu komisje są organami powołanymi do wyrażania opinii w sprawach przekazanych pod ich obrady przez Sejm, Marszałka Sejmu lub Prezydium Sejmu. Ponadto możliwe jest rozpatrzenie wspomnianych dokumentów na posiedzeniu plenarnym izby, gdyż lista spraw stanowiących przedmiot obrad na posiedzeniach Sejmu ma charakter otwarty (z powodu zastosowania w art. 169 ust. 2 regulaminu Sejmu wyrażenia „w szczególności”).

6 Pełny zapis przebiegu 12. posiedzenia Komisji Kultury i Środków Przekazu, 25 lutego 2016 r., s. 3-4. 
Jak wynika z wcześniejszych uwag, dotychczasowa praktyka postępowania w sprawie sprawozdań Rady Języka Polskiego o stanie ochrony języka polskiego obejmowała rozpatrywanie tych dokumentów przez Komisję Kultury i Środków Przekazu. Ponadto w dwóch z pięciu przypadków z ostatnich trzech kadencji izby postępowanie objęło rozpatrzenie sprawozdań przez Sejm in pleno.

\section{Ocena aktualnego stanu postępowania w sprawie rozpatrzenia „Sprawozdania o stanie ochrony języka polskiego za lata 2016-2017"}

„Sprawozdanie o stanie ochrony języka polskiego za lata 2016-2017” nosi tytuł „Język informacji politycznej”, a jego celem „było zbadanie, czy emitowane przez nadawcę publicznego, tj. Telewizję Polską S.A., tzw. paski informacyjne [...] dotyczące 13 najważniejszych wydarzeń politycznych lat 2016-2017 były zgodne" z art. 3 ust. 1 pkt 1 ustawy o języku polskim. Abstrahując od oceny zasadności omówienia tego zagadnienia przez Radę Języka Polskiego, należy stwierdzić, że przedmiotowe sprawozdanie obejmuje analizę wąskiego zakresowo problemu. W świetle przedstawionej wcześniej dotychczasowej praktyki nie jest to jednak ewenement, co nakazuje przyjąć, iż brak jest podstaw, aby twierdzić, iż wyżej wymieniony dokument nie stanowi sprawozdania, o którym mowa w art. 12 ust. 2 ustawy.

Opisane we wstępnej części opinii rozstrzygnięcie Komisji Kultury i Środków Przekazu, skutkujące odmową rozpatrzenia przedmiotowego dokumentu, stanowi de facto wyraz zanegowania decyzji Marszałka Sejmu o uznaniu tego dokumentu za sprawozdanie, o którym mowa w art. 12 ust. 2 ustawy o języku polskim przejawem tej decyzji było nadanie biegu temu dokumentowi (a w konsekwencji nadanie mu statusu druku sejmowego). Jakkolwiek w świetle powyższych uwag merytoryczna zasadność stanowiska Komisji jest wątpliwa, to trzeba podkreślić, że Komisja ma prawo do odmiennej niż Marszałek Sejmu kwalifikacji prawnej rozpatrywanego dokumentu. Swoje postępowanie powinna jednak prowadzić w ramach obowiązujących rozwiązań regulaminowych, które nie obejmują odmowy rozpatrzenia przez komisję przedmiotowego dokumentu. Ewentualna negatywna ocena sprawozdania przedłożonego przez Radę Języka Polskiego, kwestionująca zgodność tego dokumentu $\mathrm{z}$ wymogami ustawowymi, powinna zostać sformułowana $\mathrm{w}$ treści opinii przedstawianej przez Komisję. Warto przy tym podkreślić, że regulamin Sejmu nie przewiduje jakichkolwiek ograniczeń treściowych opinii komisyjnych. Oznacza to, że Komisja Kultury i Środków Przekazu nie musiałaby się w swojej opinii o sprawozdaniu zawartym w druku sejmowym nr 3324 ograniczyć do sformułowania określonej rekomendacji odnośnie do tego dokumentu (w szczególności treści „przyjąć” bądź „nie przyjąć), lecz mogłaby choćby podnieść zastrzeżenia formalne dotyczące opiniowanego dokumentu. 
Podsumowując: rozstrzygnięcie Komisji Kultury i Środków Przekazu z 2 lipca 2019 r. nie znajduje podstaw regulaminowych. Tym samym należy stwierdzić, że formalnie postępowanie komisyjne w sprawie przedmiotowego sprawozdania nie zostało zakończone. Komisja powinna powrócić do rozpatrywania tego dokumentu oraz zakończyć swoje prace, formułując stosowną opinię. 